\title{
Physiological and biochemical aspects of castor beans seeds deterioration stored in different packaging conditions and temperatures ${ }^{1}$
}

\author{
Heloisa Oliveira dos Santos², Maria Laene Moreira de Carvalho², \\ Carla Massimo Caldeira ${ }^{*}$, Stefânia Vilas Boas Coelho², \\ Edila Vilela de Resende Von Pinho ${ }^{2}$, João Almir Oliveira ${ }^{2}$
}

\begin{abstract}
The present study aimed to evaluate effects of different storage conditions on the castor bean seed cultivar IAC226 quality, stored for 12 months. For this purpose, seeds were stored in different environment and packaging conditions: in a cold chamber and conventional storage, using multiwall Kraft paper and in no vacuum and vacuum plastic packages at 1 atm; as well as under cryopreservation storage $\left(-196^{\circ} \mathrm{C}\right)$. Seed quality was evaluated before and after 4,8 and 12 months of storage by germination tests, first count of germination, emergence percentage, emergence speed index and determination of changes in catalase (CAT) and superoxide dismutase (SOD) enzyme systems. Cryopreservation $\left(-196^{\circ} \mathrm{C}\right)$ is efficient in maintaining the physiological quality of castor bean cultivar IAC-226 for 12 months. The enzyme catalase stands out as a marker of castor seed deterioration during storage.
\end{abstract}

Index terms: Ricinus communis L. storage, cryopreservation, vacuum.

\section{Aspectos bioquímicos e fisiológicos da deterioração de sementes de mamona armazenadas em diferentes embalagens e temperaturas}

\begin{abstract}
RESUMO - Objetivou-se avaliar os efeitos de diferentes condições de armazenamento sobre a qualidade de sementes de mamona cultivar IAC-226, armazenadas por um período de 12 meses. Para isso, as sementes foram armazenadas em diferentes ambientes e tipos de embalagens: em câmara fria e armazém convencional, utilizando embalagens papel Kraft multifoliado e plástico com e sem acondicionamento a vácuo a 1 atm; e também armazenamento sob criopreservação (-196 $\left.{ }^{\circ} \mathrm{C}\right)$. A qualidade das sementes foi avaliada antes e após 4, 8 e 12 meses de armazenamento pelos testes de geminação, primeira contagem de germinação, porcentagem de emergência, índice de velocidade de emergência e pela determinação das alterações nos sistemas enzimáticos catalase (CAT) e superóxido dismutase (SOD). A criopreservação $\left(-196^{\circ} \mathrm{C}\right)$ é eficiente na manutenção da qualidade fisiológica de sementes de mamona cultivar IAC-226 por 12 meses. A enzima catalase se destaca como um marcador da deterioração de sementes de mamona durante o armazenamento.
\end{abstract}

Termos para indexação: Ricinus communis L., isoenzimas, criopreservação, armazenamento.

\section{Introduction}

Castor bean is one of the major nonedible oil plants due to the great potential of this oil for use in biodiesel production (Shrirame et al., 2011) as well as in the making of pharmaceuticals and high valued polymers (Vijaya et al., 1997). However, in Brazil, productivity of this culture is still low, compared to other oilseeds such as soybean, peanut and sunflower (Fanan et al., 2009). One of the factors that contribute to this low productivity is the high content of oil in the seeds, 40 to $55 \%$ (Scholz and Silva, 2008), which makes storage of these seeds more difficult.

Preservation of the seeds quality during storage, after their physiological maturity, depends on the species lifespan, its initial quality and storage conditions (Probert et al., 2007; Cardoso et al., 2012). Temperature and relative humidity are often cited as some of the key factors that affect adversely the seeds quality during storage, causing physical and chemical changes such as loss of the cell membrane integrity, decreased enzymatic activity, lipids peroxidation (Ellis and Hong, 2006; Oge et al., 2008) and, consequently, loss of vigor.

To ensure long-term quality of castor bean seeds, whether

${ }^{1}$ Submitted on 06/14/2016. Accepted for publication on 08/01/2016.

${ }^{2}$ Departamento de Agricultura, UFLA, Caixa Postal 3037, 37200-000 - Lavras, MG, Brasil.

"Corresponding author <carlaufla@yahoo.com.br> 
for marketing purposes or for preservation of genetic material, some techniques have been tested, among them storage of the seeds under sub-zero temperatures (Reed et al., 2011, Lopes et al., 2013). For better preservation of orthodox seeds, such as those of castor bean plants, environments with low relative humidity and temperature have proven to be appropriate, because such conditions, according to Chmielarz (2010), allow maintaining a low level of activity of the chemical reactions and preservation of the seeds germinative power and vigor.

One of the alternatives for the study of seeds deterioration is the analysis of isoenzyme groups, which allows identifying the starting points of damages and providing reliable information on the actual causes of the deteriorative events and their consequences. Among the free radical-scavenging enzymes that are formed during the seeds deterioration process, Nkang et al. (2000) point catalase, peroxidase and superoxide dismutase as the major ones. Several authors working with seeds having high oil contents found a decrease in the activity of the catalase and superoxide dismutase enzymes as the storage time increased (Sharma et al., 2013; Goel et al., 2003; Sung, 1996) and a diminished survival rate compared with non-oil seeds (Nagel and Borner, 2010).

Even though seeds storage under controlled conditions has already been practiced by large companies in the industry, reflecting a concern in preserving the quality of the seeds produced, up to now there have been difficulties in establishing the best storage conditions and specific preservation methods for castor bean seeds. According to Chen et al. (2010), knowledge on the seeds behavior during deterioration is essential for making appropriate decisions on handling and storage conditions.

Thus, this study aimed to assess the effects of different storage conditions on the quality of the seeds of castor plant cultivar IAC-226 stored for 12 months.

\section{Material and Methods}

The experiment was conducted at the Laboratory for Seeds Testing, Federal University of Lavras, MG, using castor bean seeds, cultivar IAC-226, harvested in 2009.

The seeds quality was assessed before and after four, eight and twelve months of storage, thus comprising four periods of assessment. The seeds were homogenized and stored under different conditions, as follows:

In conventional storage (ambient, $25^{\circ} \mathrm{C}$ ) and in dry and cold chamber $\left(10{ }^{\circ} \mathrm{C}\right.$ and $\left.40 \% \mathrm{RH}\right)$, in multiwall Kraft paper bags, and in no vacuum and vacuum polyethylene packages (0.1 atm).

In liquid nitrogen (cryopreservation at $-196{ }^{\circ} \mathrm{C}$ ) in aluminum coated paper bags, resulting in seven storage conditions $(\mathrm{CS} / \mathrm{Pb}$ - conventional storage and paper bag;
$\mathrm{CS} / \mathrm{Pl}$ - conventional storage and plastic bag; CS/Va conventional storage and vacuum packing bag; $\mathrm{Cc} / \mathrm{Pb}$ - cold chamber and paper bag; $\mathrm{Cc} / \mathrm{Pl}$ - cold chamber and plastic bag; $\mathrm{Cc} / \mathrm{Va}$ - cold chamber and vacuum packing bag; and Cryo cryopreservation.

For cryopreservation, the packaged seeds were soaked directly in liquid nitrogen. After each cryopreservation period (4, 8 and 12 months), the seeds bags were taken out from liquid nitrogen and let thawing at ambient temperature for 24 hours.

To assess the seeds physiological quality, tests to determine germination, first count of germination, emergence, and emergence speed index were carried out.

The germination test was conducted with four replications of 50 seeds sown between sheets of paper towel moistened with distilled water at a 2.5 ratio to the substrate weight. The seeds remained in the germinator at $25^{\circ} \mathrm{C}$ and the assessments were conducted at 7 and 14 days after sowing to determine the first germination count and final germination, with results expressed in percentage (Brasil, 2009).

The seedling emergence test was conducted with four replications of 50 seeds sown in plastic trays, containing a substrate made up of a 2:1 mixture of soil and sand, which was moistened to $70 \%$ of the water holding capacity. The trays were maintained in a growing chamber at $25^{\circ} \mathrm{C}$. Daily assessments were conducted to obtain the emergence speed index - ESI (Maguire, 1962) and at 14 days to obtain the final emergence percentage.

For the enzymatic analysis, $300 \mu \mathrm{L}$ aliquots of $50 \%$ acetone were added to the $100 \mathrm{mg}$ samples of ground material and centrifuged at $14000 \mathrm{rpm}$ for 30 minutes at $4{ }^{\circ} \mathrm{C}$ to remove excess oil. After discarding the supernatant, $300 \mu \mathrm{L}$ of the extraction buffer $(0.2 \mathrm{M}$ Tris, $0.1 \%$ b-mercaptoethanol) was added. The homogenized material was incubated in ice for 24 hours and centrifuged at $14000 \mathrm{rpm}$ at $4{ }^{\circ} \mathrm{C}$ for 30 minutes.

To proceed with the electrophoretic run, $50 \mu \mathrm{L}$ of the supernatant was applied into the gel channels, and electrophoresis was carried out at $4{ }^{\circ} \mathrm{C}, 120 \mathrm{~V}$, for 6 hours. After electrophoresis, the gels were stained to detect the activity of the catalase and superoxide dismutase enzymes, following the method described by Alfenas et al. (2006). For the superoxide dismutase, extraction and development were carried out in the presence of a specific substrate for the enzyme.

A completely randomized experimental design was used, and data were statistically interpreted by analysis of variance in a $4 \times 7$ factorial scheme, consisting of four storage times $(0,4$, 8 , and 12 months) and seven storage conditions (conventional storage - $\mathrm{CS}$ and paper bags - $\mathrm{Pb}$; conventional storage - CS and plastic bags - Pl; conventional storage - $\mathrm{CS}$ and vacuum packages - Va; cold chamber - $\mathrm{Cc}$ and paper bags - $\mathrm{Pb}$; 
cold chamber - Cc and plastic bags - Pl; cold chamber - Cc and vacuum packages - Va; and Cryopreservation - Cryo). The means were compared by the Scott-Knott's test at a 5\% probability level, except for the activities determination, and for the quantitative factor (storage time), when significant. The statistical analyses were performed using the R software (R Development Team, 2011).

\section{Results and Discussion}

For all tests performed, there was a significant interaction between the storage conditions and time.

For the first count of germination, differences in the storage conditions could be observed only after four months of storage (Table 1). However, when comparing the different storage conditions, there was no pattern of seed germination. This can be due to the difficulty of the seeds in absorbing water because of the integument thickness and rigidity or a possible postharvest dormancy, represented by the integument hardness, which could have hindered the initial seeds germination (Copeland and Mcdonald, 1995; Vasconcelos et al., 2010).

Until four months of storage, all treatments exhibited germination above $90 \%$, and no differences were observed between the treatments studied (Table 2). However, at 12 months of storage, the quality of the seeds under cryopreservation was higher than the other storage conditions, exhibiting a germination above $90 \%$. There were no significant losses in the quality of the castor plant seeds under cryopreservation during 12 months of storage, corroborating results found by Rocha et al. (2009) in cotton plant seeds and by Zhang et al. (2014) in citrus embryos preservation. Similarly, Vargas et al. (2009) recommends cryopreservation to preserve pollen grains of different cultivars of castor plant with low water contents. However, Almeida et al., (2002) states that cryoperservation was not effective in preserving seeds from castor plant cv. Nordestina and Pernambucana for 60 days. It should be noted that Almeida et al. (2002)'s results were obtained after short-term storage, i.e. 30 days under cryopreservation and by using a slow freezing method, whereby the seeds temperature was reduced gradually, and fast thawing in water bath at $40{ }^{\circ} \mathrm{C}$, which could have affected the results. These conditions were different from those used in this study, i.e. medium-term storage (12 months), using the fast freezing method, whereby the seeds were immersed directly into liquid nitrogen, and slow thawing at $22{ }^{\circ} \mathrm{C}$ for 24 hours.

Table 1. Mean values (\%) of germination at first count of castor bean plant cv. IAC-226 in the first count of germination, as a function of storage time ( $0,4,8$ and 12 months) and storage conditions ( $\mathrm{CS} / \mathrm{Pb}$ - conventional storage and paper bag; $\mathrm{CS} /$ $\mathrm{Pl}$ - conventional storage and plastic bag; $\mathrm{CS} / \mathrm{Va}$ - conventional storage and vacuum package; $\mathrm{Cc} / \mathrm{Pb}$ - cold chamber and paper bag; $\mathrm{Cc} / \mathrm{Pl}$ - cold chamber and plastic bag; $\mathrm{Cc} / \mathrm{Va}$ - cold chamber and vacuum package; and Cryo - cryopreservation.

\begin{tabular}{cccccccc}
\hline \multirow{2}{*}{ Time } & \multicolumn{5}{c}{ Storage conditions } \\
\cline { 2 - 7 } & $\mathrm{CS} / \mathrm{Pb}$ & $\mathrm{CS} / \mathrm{Pl}$ & $\mathrm{CS} / \mathrm{Va}$ & $\mathrm{Cc} / \mathrm{Pb}$ & $\mathrm{Cc} / \mathrm{Pl}$ & $\mathrm{Cc} / \mathrm{Va}$ & $\mathrm{Cryo}$ \\
\hline 0 & $51 \mathrm{Ba}$ & $52 \mathrm{Aa}$ & $49 \mathrm{Ba}$ & $39 \mathrm{Ba}$ & $42 \mathrm{Aa}$ & $40 \mathrm{Ba}$ & $47 \mathrm{Ca}$ \\
4 & $41 \mathrm{Bc}$ & $41 \mathrm{Ac}$ & $43 \mathrm{Bc}$ & $46 \mathrm{Bc}$ & $57 \mathrm{Ab}$ & $74 \mathrm{Aa}$ & $62 \mathrm{Bb}$ \\
8 & $63 \mathrm{Ab}$ & $58 \mathrm{Ab}$ & $73 \mathrm{Aa}$ & $77 \mathrm{Aa}$ & $57 \mathrm{Ab}$ & $66 \mathrm{Ab}$ & $79 \mathrm{Aa}$ \\
12 & $55 \mathrm{Aa}$ & $53 \mathrm{Aa}$ & $60 \mathrm{Aa}$ & $38 \mathrm{Bb}$ & $54 \mathrm{Aa}$ & $42 \mathrm{Bb}$ & $44 \mathrm{Cb}$ \\
\hline $\mathrm{CV}(\%)$ & & & 17.13 & & & \\
\hline
\end{tabular}

Means followed by the same uppercase letter in columns and lowercase letter in rows do not differ statistically by the Scott-Knott test at $5 \%$ level.

Table 2. Mean values ( $\%)$ of seeds germination of castor bean plant $\mathrm{cv}$. IAC-226 as a function of the storage time $(0,4,8$ and 12 months) and conditions ( $\mathrm{CS} / \mathrm{Pb}$ - conventional storage and paper bag; $\mathrm{CS} / \mathrm{Pl}$ - conventional storage and plastic bag; $\mathrm{CS} / \mathrm{Va}$ - conventional storage and vacuum package; $\mathrm{Cc} / \mathrm{Pb}$ - cold chamber and paper bag; $\mathrm{Cc} / \mathrm{Pl}$ - cold chamber and plastic bag; $\mathrm{Cc} / \mathrm{Va}$ - cold chamber and vacuum package, and Cryo - cryopreservation.

\begin{tabular}{cccccccc}
\hline \multirow{2}{*}{ Time } & \multicolumn{5}{c}{ Storage conditions } \\
\cline { 2 - 7 } & $\mathrm{CS} / \mathrm{Pb}$ & $\mathrm{CS} / \mathrm{Pl}$ & $\mathrm{CS} / \mathrm{Va}$ & $\mathrm{Cc} / \mathrm{Pb}$ & $\mathrm{Cc} / \mathrm{Pl}$ & $\mathrm{Cc} / \mathrm{Va}$ & $\mathrm{Cryo}$ \\
\hline 0 & $98 \mathrm{Aa}$ & $97 \mathrm{Aa}$ & $97 \mathrm{Aa}$ & $98 \mathrm{Aa}$ & $97 \mathrm{Aa}$ & $98 \mathrm{Aa}$ & $98 \mathrm{Aa}$ \\
4 & $95 \mathrm{Aa}$ & $91 \mathrm{Aa}$ & $94 \mathrm{Aa}$ & $92 \mathrm{Aa}$ & $92 \mathrm{Aa}$ & $91 \mathrm{Aa}$ & $97 \mathrm{Aa}$ \\
8 & $79 \mathrm{Bc}$ & $84 \mathrm{Bb}$ & $92 \mathrm{Aa}$ & $80 \mathrm{Bc}$ & $63 \mathrm{Bd}$ & $76 \mathrm{Bc}$ & $97 \mathrm{Aa}$ \\
12 & $57 \mathrm{Cb}$ & $59 \mathrm{Cb}$ & $66 \mathrm{Bb}$ & $47 \mathrm{Cc}$ & $62 \mathrm{Bb}$ & $57 \mathrm{Bb}$ \\
\hline $\mathrm{CV}(\%)$ & & & 7.45 & & & \\
\hline
\end{tabular}

Means followed by the same uppercase letter in columns and lowercase in rows do not differ statistically by the Scott-Knott test at $5 \%$ level. 
Cryopreservation was effective in preserving the physiological quality of castor seeds during storage compared to the other conditions tested. The seeds preserved in liquid nitrogen, even after 12 months of storage, exhibited germination rates higher than the standard values described in the regulation no. 45 of Sept. 13, 2013 for seeds marketing, which specifies a minimum of $80 \%$ for castor plant seeds (Brasil, 2013). This did not occur with the seeds preserved by other methods. Confirming the results found in the germination test, it was possible to observe significantly higher percentages of speed and emergence for the seeds stored in liquid nitrogen for 12 months, when compared to the other storage conditions (Table 3 and 4). For the seeds stored by the conventional method, it could be seen at the end of 12 months of storage a higher emergence rate when the seeds were vacuum packaged. However, when stored in cold chamber, vacuum packaging affected adversely the seeds emergence. Camargo and Carvalho (2008) concluded that vacuum packaging associated with low temperatures could affect adversely the quality of sweet corn seeds and lead to an increased anaerobic respiration of the seeds, which was confirmed by the high activity of alcohol dehydrogenase (ADH) enzymes. These findings confirm that the joint action of oxygen restriction and low temperatures speed up the deterioration process of orthodox seeds, such as those from castor bean plants, reducing their longevity.

Table 3. Mean values (\%) of seedlings emergence of castor bean plant cv. IAC-226 as a function of the seeds storage time $(0$, 4, 8 and 12 months) and conditions ( $\mathrm{CS} / \mathrm{Pb}$ - conventional storage and paper bag; $\mathrm{CS} / \mathrm{Pl}$ - conventional storage and plastic bag; $\mathrm{CS} / \mathrm{Va}$ - conventional storage and vacuum package; $\mathrm{Cc} / \mathrm{Pb}$ - cold chamber and paper bag; $\mathrm{Cc} / \mathrm{Pl}$ - cold chamber and plastic bag; $\mathrm{Cc} / \mathrm{Va}$ - cold chamber and vacuum package; and Cryo - cryopreservation.

\begin{tabular}{cccccccc}
\hline \multirow{2}{*}{ Time } & \multicolumn{5}{c}{ Storage conditions } \\
\cline { 2 - 7 } & $\mathrm{CS} / \mathrm{Pb}$ & $\mathrm{CS} / \mathrm{Pl}$ & $\mathrm{CS} / \mathrm{Va}$ & $\mathrm{Cc} / \mathrm{Pb}$ & $\mathrm{Cc} / \mathrm{Pl}$ & $\mathrm{Cc} / \mathrm{Va}$ & $86 \mathrm{Ab}$ \\
\hline 0 & $89 \mathrm{Ab}$ & $90 \mathrm{Ab}$ & $86 \mathrm{Bb}$ & $89 \mathrm{Ab}$ & $88 \mathrm{Aa}$ \\
4 & $82 \mathrm{Bc}$ & $90 \mathrm{Ab}$ & $92 \mathrm{Ab}$ & $91 \mathrm{Ab}$ & $84 \mathrm{Ab}$ & $92 \mathrm{Ac}$ & $98 \mathrm{Aa}$ \\
8 & $71 \mathrm{Cd}$ & $85 \mathrm{Ab}$ & $87 \mathrm{Bb}$ & $84 \mathrm{Bb}$ & $78 \mathrm{Bc}$ & $88 \mathrm{Bb}$ & $96 \mathrm{Aa}$ \\
12 & $53 \mathrm{Dd}$ & $65 \mathrm{Bc}$ & $75 \mathrm{Cb}$ & $51 \mathrm{Cd}$ & $65 \mathrm{Cc}$ & $49 \mathrm{Cd}$ & $83 \mathrm{Ba}$ \\
\hline $\mathrm{CV}(\%)$ & & & 4.52 &
\end{tabular}

Means followed by the same uppercase letter in columns and lowercase in rows do not differ statistically by the Scott-Knott test and F-test at $5 \%$ level.

Table 4. Emergence speed index of castor bean plant cv. IAC-226 as a function of the seeds storage time $(0,4,8$ and 12 months) and conditions ( $\mathrm{CS} / \mathrm{Pb}$ - conventional storage and paper bag; $\mathrm{CS} / \mathrm{Pl}$ - conventional storage and plastic bag; $\mathrm{CS} / \mathrm{Va}$ - conventional storage and vacuum package; $\mathrm{Cc} / \mathrm{Pb}$ - cold chamber and paper bag; $\mathrm{Cc} / \mathrm{Pl}$ - cold chamber and plastic bag; $\mathrm{Cc} / \mathrm{Va}$ - cold chamber and vacuum package; and Cryo - cryopreservation.

\begin{tabular}{cccccccc}
\hline \multirow{2}{*}{ Time } & \multicolumn{5}{c}{ Storage conditions } \\
\cline { 2 - 7 } & $\mathrm{CS} / \mathrm{Pb}$ & $\mathrm{CS} / \mathrm{Pl}$ & $\mathrm{CS} / \mathrm{Va}$ & $\mathrm{Cc} / \mathrm{Pb}$ & $\mathrm{Cc} / \mathrm{Pl}$ & $\mathrm{Cc} / \mathrm{Va}$ & $5.35 \mathrm{Ab}$ \\
\hline 0 & $5.65 \mathrm{Ab}$ & $5.51 \mathrm{Ab}$ & $5.21 \mathrm{Ab}$ & $5.37 \mathrm{Ab}$ & $5.37 \mathrm{Ab}$ & $7.92 \mathrm{Aa}$ \\
4 & $5.31 \mathrm{Ab}$ & $5.28 \mathrm{Ab}$ & $4.96 \mathrm{Ab}$ & $5.05 \mathrm{Ab}$ & $4.99 \mathrm{Ab}$ & $5.13 \mathrm{Ab}$ & $7.73 \mathrm{Aa}$ \\
8 & $4.82 \mathrm{Bb}$ & $4.72 \mathrm{Bb}$ & $4.51 \mathrm{Bb}$ & $4.73 \mathrm{Bb}$ & $4.60 \mathrm{Bb}$ & $4.44 \mathrm{Bb}$ & $7.45 \mathrm{Aa}$ \\
12 & $3.32 \mathrm{Cb}$ & $3.26 \mathrm{Cb}$ & $3.41 \mathrm{Cb}$ & $3.31 \mathrm{Cb}$ & $2.94 \mathrm{Cb}$ & $1.60 \mathrm{Cc}$ & $4.24 \mathrm{Ba}$ \\
\hline $\mathrm{CV}(\%)$ & & & 5.91 & &
\end{tabular}

Means followed by the same uppercase letter in columns and lowercase in rows do not differ statistically by the Scott-Knott test and F-test at $5 \%$ level.

In the first count of germinated seeds, a decreased vigor could be seen after eight months of storage for all treatments (Figure 1A). Regarding germination and seedling emergence, even with reduced germination after the fourth month, cryopreservation was still better, when compared to the other conditions tested at the end of 12 months of storage. This once again clearly shows the positive influence of cryopreservation in maintaining the quality of castor seeds (Figures $1 \mathrm{~B}$ and $\mathrm{C}$ ).
Even having better results than the other conditions tested, the seeds stored in liquid nitrogen only had a sharp reduction in the emergence rate after the eighth month of storage. For the seeds stored in vacuum packages and cold chamber, a sharp reduction of the emergence rate occurred at 12 months of storage (Figure 1D).

According to Finch-Savage et al. (2007), dormancy can be overcome by high or low temperatures, depending on the 
plant species. However, this effect was not observed for castor seeds because the seeds stored in cold chamber at an average temperature of $10{ }^{\circ} \mathrm{C}$ did not exhibit better results than the seeds stored conventionally, which indicates that dormancy in castor seeds is integumentary and immersion in liquid nitrogen could be an alternative to overcome it.

The isoenzyme profiles revealed for the superoxide dismutase an increased activity of the cryopreserved seeds during storage (Figure 2a). When oxidative damage occurs in the membranes, crosslinks between the proteins and phospholipids are formed, resulting in the destruction of the spatial arrangement of the membrane, causing an irreversible damage to its structure (Henning et al., 2010). In this case, storing these seeds under sub-zero temperatures (cryopreservation) may have preserved the integrity of the cellular membranes for a longer period of time. However, for the other seed storage conditions, it was not possible to detect any difference in this enzyme activity.
A

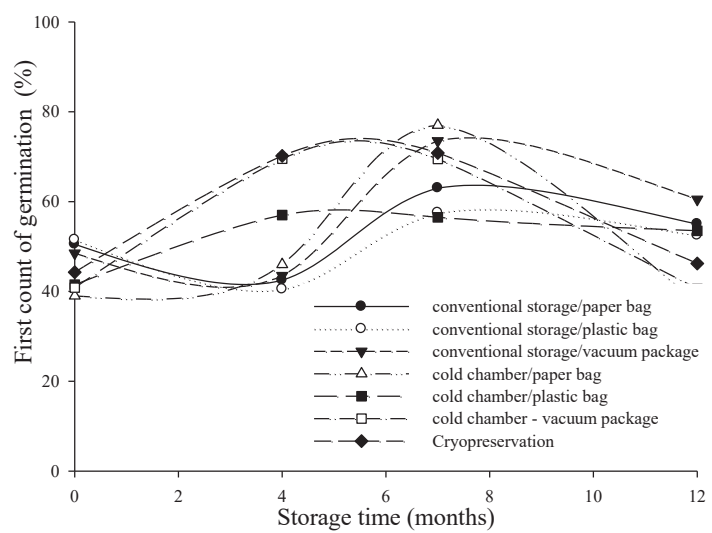

$\mathrm{C}$

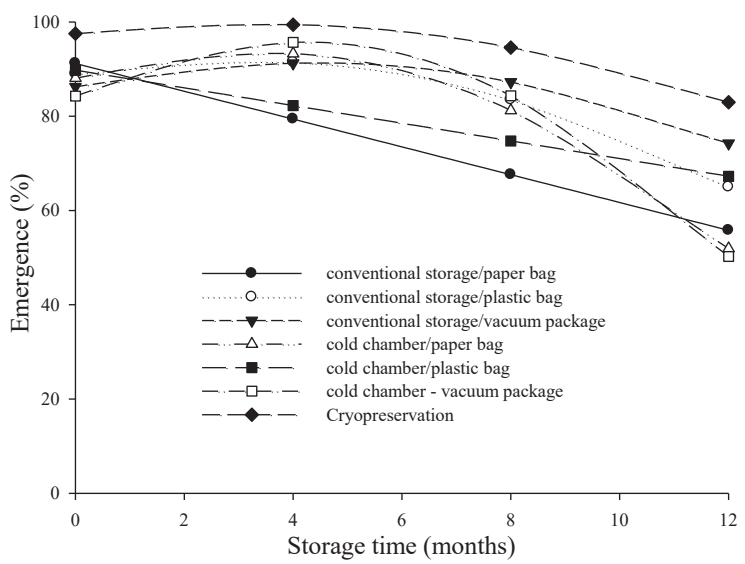

B

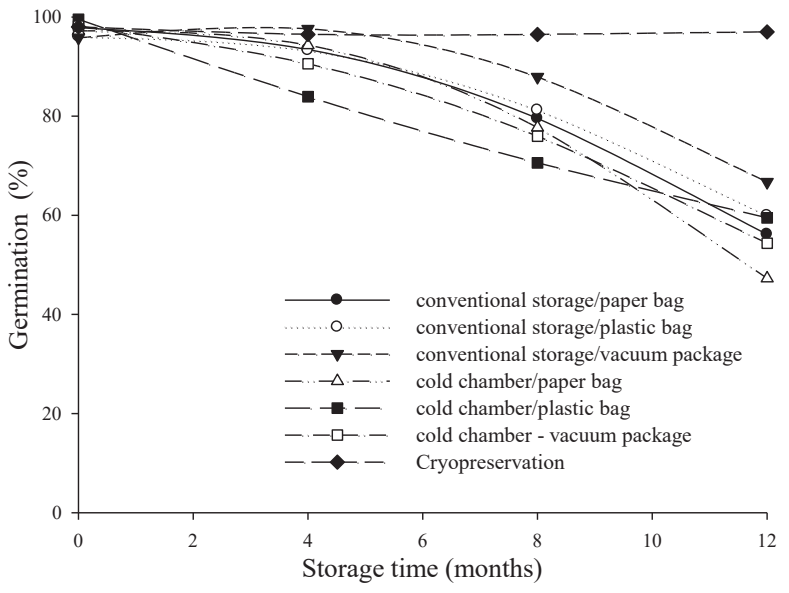

$\mathrm{D}$

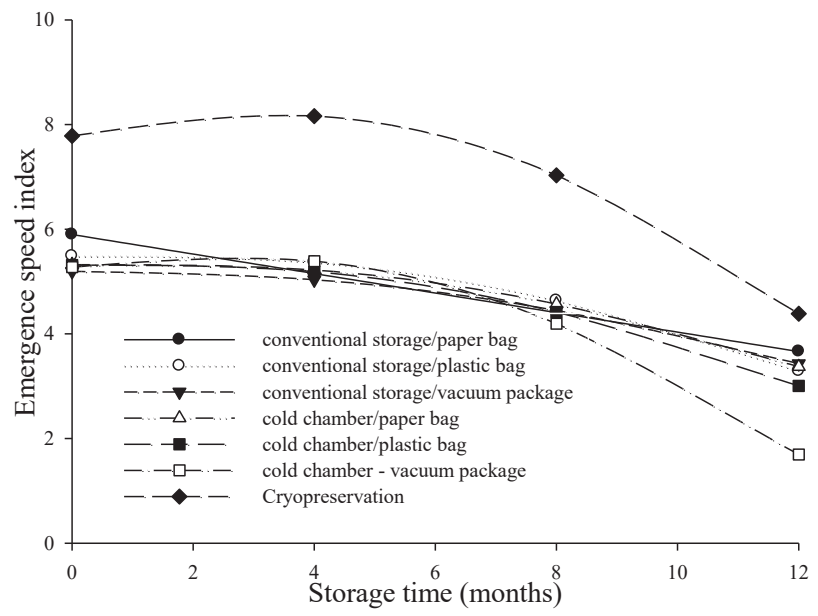

Figure 1. First count of germination (A), Germination (B), Emergence (C) and (D) Emergence speed index of castor bean seeds as a function of the storage time $(0,4,8$ and 12 months) and storage conditions. 

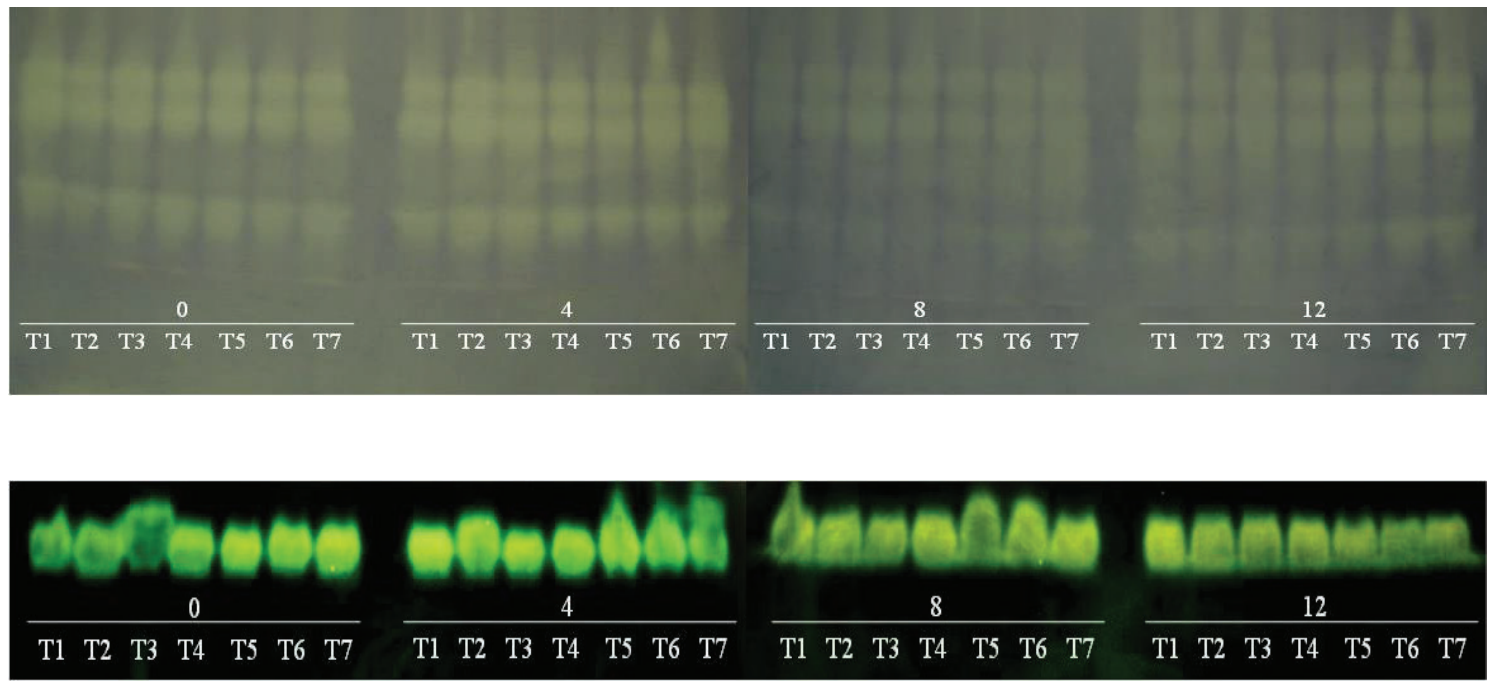

Figure 2. Isoenzyme patterns of castor plant seeds, cultivar IAC-226, subjected to different storage times $(0,4,8$ and 12 months) and conditions (T1: conventional storage/paper bag, T2: conventional storage/plastic bag; T3: conventional storage/vacuum package; T4: cold chamber/paper bag; T5: cold chamber/plastic bag; T6: cold chamber - vacuum package, and T7: Cryopreservation) revealed for superoxide dismutase (A) and catalase (B).

Storage-induced stress, especially in non-controlled environmental conditions, activated the seeds metabolism, triggering oxidative processes and the production of free radicals. This is demonstrated by the greater activity of the catalase (CAT) enzyme at zero time for the seeds stored in ambient conditions. In the subsequent periods of storage, there is a reduction in the CAT activity in the same conditions, which can be associated with the presence of oxygen as well as the deterioration level, because in more spoiled seeds there is a considerable reduction of this activity, leading to the enzyme inactivation (Figure $2 b$ ).

Catalase, which is an enzyme involved in the decomposition of hydrogen peroxide, plays a role in the control of these endogenous peroxides through the oxidation-reduction cycle (Sabeva and Nedeva, 2008). Thus, a reduction of the activity of this enzyme may result in a decrease of oxidative injuries to seeds, which can explain the results found in this study on castor oilseeds. Carneiro et al. (2011) also observed a decrease in the catalase activity associated with loss of viability of sunflower seeds. Therefore, this evaluation suggests that catalase can be a deterioration marker for castor plant seeds.

\section{Conclusions}

Cryopreservation $\left(-196^{\circ} \mathrm{C}\right)$ is effective in maintaining the physiological quality of castor bean seeds, cultivar IAC-226, for 12 months.

The catalase enzyme can be considered a marker of deterioration of castor bean seeds during storage.

\section{Acknowledgement}

The study received financial support from the National Council for Scientific and Technological Development $(\mathrm{CNPq})$, which is gratefully acknowledged.

\section{References}

ALFENAS, A. C. (Ed.). Eletroforese e marcadores bioquímicos em plantas e microrganismos.2.ed. Viçosa: UFV, 2006. 627p.

ALMEIDA, F.A.C.; MORAIS, A. M.; CARVALHO, J. M. F. C.; GOUVEIA, J. P. G. Crioconservação de sementes de mamona das variedades nordestina e pernambucana. Revista Brasileira de Engenharia Agricola e Ambiental, v.6, n.2, p.295-302, 2002. http://www.scielo.br/pdf/rbeaa/v6n2/v6n2a19.pdf

BRASIL. Diário Oficial da União. Padrões para produção e comercialização de sementes de mamona. Brasília, DF, n45, 2013. Seção 1, p.21-23. http://www. abrasem.com.br/wp-content/uploads/2012/10/Instru\%C3\%A7\%C3\%A3oNormativa-n $\%$ C2\%BA-45-de-17-de-Setembro-de-2013-Padr $\%$ C3\%B5esde-Identidade-e-Qualiidade-Prod-e-Comerc-de-Sementes-Grandes-Culturas-Republica\%C3\%A7\%C3\%A3o-DOU-20.09.13.pdf

BRASIL. Ministério da Agricultura, Pecuária e Abastecimento. Regras para análise de sementes. Ministério da Agricultura, Pecuária e Abastecimento. Secretaria de Defesa Agropecuária. Brasília: MAPA/ACS, 2009, 395p. http:// www.agricultura.gov.br/arq_editor/file/2946_regras_analise_sementes.pdf

CAMARGO, R.; CARVAlHO, M. L. M. Armazenamento a vácuo de semente de milho doce. Revista Brasileira de Sementes, v.30, n.1, p.131-139, 2008. http://www.scielo.br/pdf/rbs/v30n1/a17v30n1.pdf 
CARDOSO, R. B.; BINOTTI, F. F. S.; CARDOSO, E. D. Potencial fisiológico de sementes de crambe em função de embalagens e armazenamento. Pesquisa Agropecuária Tropical, v.42, n.3, p.272-278, 2012. http://www.scielo.br/pdf/ pat/v42n3/a04v42n3.pdf

CARNEIRO, M. M. L.; DEUNER, S.; OLIVEIRA, P. V.; TEIXEIRA, S. B.; SOUSA, C. P.; BACARIN, M. A.; MORAES, D. M. Atividade antioxidante e viabilidade de sementes de girassol após estresse hídrico e salino. Revista Brasileira de Sementes, v.33, n.4 p.752 -761, 2011. http://www.scielo.br/pdf/ rbs/v33n4/17.pdf

CHEN, S.Y.; CHIEN, C.T. ; BASKIN, J. M.; BASKIN, C. C. Storage behavior and changes in concentrations of abscisic acid and gibberellins during dormancy break and germination in seeds of Phellodendron amurense var. wilsonii (Rutaceae). Tree Physiology, v.30, p.275-284, 2010. http://www. ncbi.nlm.nih.gov/pubmed/20008838.

CHMIELARZ, P. Cryopreservation of dormant orthodox seeds of European hornbeam (Carpinus betulus) Seed Science and Technology, v.38, n.1, p.146-157, 2010. http://www.ingentaconnect.com/contentone/ ista/sst/2010/00000038/00000001/art00015.

COPELAND, L. O.; MCDONALD, M. B. Principles of seed science and technology. New York: Chapmam \& Hall, 1995. 409p.

ELLIS, R.H; HONG, T.D. Temperature sensitivity of the low-moisturecontent limit to negative seed longevity-moisture content relationships in hermetic storage. Annals of Botany, v.78, p.785-791, 2006. http://aob. oxfordjournals.org/content/97/5/785.full.pdf $+\mathrm{html}$

FANAN, S.; MEDINA, P. F.; CAMARGO, M. B. P.; RAMOS, N. P. Influência da colheita e do armazenamento na qualidade fisiológica de sementes de mamona. Revista Brasileira de Sementes, v.31, n.1, p. 150-159, 2009. http:// www.scielo.br/pdf/rbs/v31n1/a17v31n1.pdf

FINCH-SAVAGE, W. E.; CADMAN, C. S. C.; TOOROP, P. E.; LYNN, J. R.; HILHORST, H. W. M. Seed dormancy release in Arabidopsis Cvi by dry afterripening, low temperature, nitrate and light shows common quantitative patterns of gene expression directed by environmentally specific sensing. The Plant Journal, v.51, n.4, p.60-78, 2007. http://onlinelibrary.wiley.com/ doi/10.1111/j.1365-313X.2007.03118.x/epdf

GOEL, A.; GOEL, A. K.; SHEORAN, I. S. Changes in oxidative stress enzymes during artificial ageing in cotton (Gossypium hirsutum L.) seeds. Journal Plant Physiology, v.160, n. 9, p.1093-1100, 2003. http://www. sciencedirect.com/science/article/pii/S0176161704704988

HENNING, F.A.; MERTZ, L.M.; JACOB JUNIOR, E.A.; MACHADO, R.D.; FISS, G.; ZIMMER, P.D. Composição química e mobilização de reservas em sementes de soja de alto e baixo vigor. Bragantia, v.69, n.3. p.727-734, 2010. http://www.scielo.br/pdf/brag/v69n3/26.pdf.

LOPES, K. P.; ALMEIDA, F. A. C.; CARVALHO, J. M. F. C.; BRUNO, R. L. A. Criopreservação de eixo embrionário zigótico de algodoeiro. Revista Brasileira de Engenharia Agricola e Ambiental, v. 17, n. 3, p.291-298, 2013. http://www.scielo.br/pdf/rbeaa/v17n3/07.pdf

MAGUIRE, J. D. Speeds of germination aid selection and evaluation for seedling emergence and vigor. Crop Science, v.2, n. 2, p. 176-177, 1962.

NAGEL, M.; BÖRNER, A. The longevity of crop seeds stored under ambient conditions. Seed Science Research, v.20, p.1-12, 2010. http://journals. cambridge.org/action/displayFulltext?type $=1 \&$ fid $=7169392 \&$ jid=SSR\&volumeId $=20$ \&issueId $=01$ \&aid $=7169384$.

NKANG, A.; OMOKARO, D.; EGBE, A. Effects of desiccation on the lipid peroxidation and activities of peroxidase and polyphenoloxidase in seeds of Telfairia occidentalis. Seed Science and Technology, v. 28, n.1, p. 1-9, 2000. https://www.cabdirect.org/cabdirect/abstract/20000310568.
OGE, L.; BOURDAIS, G.; BOVE, J.; COLLET, B.; GODIN, B.; GRANIER, F.; BOUTIN, J. P.; JOB, D.; JULLIEN, M.; GRAPPIN, P. Protein repair L-isoaspartyl methyltransferase 1 is involved in both seed longevity and germination vigor in Arabidopsis. Plant Cell, v.20, n. 11, p. 3022 - 3037, 2008. http://www.ncbi.nlm.nih.gov/pmc/articles/PMC2613667/

PROBERT, R.; ADAMS, J.; CONEYBEER, J.; CRAWIORD, A.; HAY, F. Seed quality for conservation is critically affected by pre-storage factors. Australian Journal of Botany, v.55, n.3, p.326-335, 2007. http://www. publish.csiro.au/paper/BT06046.htm

R- Development Core Team. R: A Language and Environment for Statistical Computing. Vienna, Austria: the R Foundation for Statistical Computing, 2011. http://www.R-project.org/.

REED, B.M.; SARASAN, V.; KANE, M; BUNN, E.; PENCE, VC. Biodiversity conservation and conservation biotechnology tools. In Vitro Cellular \& Developmental Biology -Plant, v.47, n.1, p.1- 4, 2011. http://link. springer.com/article/10.1007\%2Fs11627-010-9337-0

ROCHA, M. S.; CAVALCANTI MATA, M. E. R. M.; CARVALHO, J. M. F. C.; LOPES, K. P. Crioconservação de sementes de algodão. Revista Brasileira de Engenharia Agrícola e Ambiental, v.13, n.3, 2009. http://www. scielo.br/pdf/rbeaa/v13n3/v13n03a13.pdf

SABEVA, S.; NEDEVA, D. Antioxidant enzymes in germinating wheat seeds as affected by dehydration stress, ABA and hydrogen peroxide. Acta Agronomica Hungarica, v.56, n.2, p. 113-127, 2008. http://www.akademiai. com/doi/abs/10.1556/AAgr.56.2008.2.1?journalCode $=014$.

SCHOLZ, V.; SILVA, J.N. Prospects and risks of the use of castor oil as a fuel. Biomass and Bioenergy, v.32, n.2, p.95-100, 2008. http://www.sciencedirect. com/science/article/pii/S0961953407001481

SHARMA, S.; AMANDEEP, K.; ABHEY, B. Positional effects on soybean seed composition during storage. Journal of Food Science and Technology-Mysore, v.50, p.353-359, 2013. http://www.ncbi.nlm.nih.gov/pmc/articles/PMC3550907/

SHRIRAME, H.Y.; PANWAR, N.L.; BAMNIYA, B.R. Bio diesel from castor oil- a green energy option. Low Carbon Economy, v.2, p.1-6, 2011. http://file. scirp.org/pdf/LCE20110100005_63987199.pdf

SUNG, J. M. Lipid peroxidation and peroxide scavenging in soybean seeds during ageing. Physiologia Plantarum, v.97, n.1, p.85-89, 1996. http:// onlinelibrary.wiley.com/doi/10.1111/j.1399-3054.1996.tb00482.x/epdf

VARGAS, D. P.; SOUZA, S.A.M.; SILVA, S.D.A.; BOBROWSKI, V. L. Análise dos grãos de pólen de diferentes cultivares de manona (Ricinus communis L., Euphorbiaceae): conservação e viabilidade. Arquivos do Instituto Biológico, v.76, n.1, p.115-120, 2009. http://www.biologico.sp.gov. br/docs/arq/v76_1/vargas.pdf

VASCONCELOS, J. M.; CARDOSO, T. V.; SALES, J. F.; SILVA, F. G.; VASCONCELOS FILHO, S. C.; SANTANA, J. G. Métodos de superação de dormência em sementes de croada (Mouriri elliptica Mart). Ciência Agrotecnologia, v.34, n.5, 2010. http://www.scielo.br/pdf/cagro/v34n5/17.pdf

VIJAYA, K.P.; RAMAKRISHNA, Y.S.; RAO, B.V.R.; VICTOR, U.S.; SRIVASTAVA, N.N.; SUBBA RAO, A.V.M. Influence of moisture, thermal and photoperiodic regimes on the productivity of castor beans (Ricinus communis L.). Agricultural and Forest Meteorology, v.88, n.1-4, p.279-289, 1997. http://www.sciencedirect.com/science/article/pii/S0168192397000191

ZHANG, N.; WEN, B.; JI, MY.; YAN, Q. Low-temperature storage and cryopreservation of grapefruit (Citrus paradisi Macfad.) seeds. Cryo Letters, v.35, n.5, p.418-426, 2014. http://www.ncbi.nlm.nih.gov/pubmed/25397957. 